\title{
PENERAPAN MODEL CREATIVE PROBLEM SOLVING BERBASIS KOMIK STRIP DALAM PEMBELAJARAN FISIKA UNTUK MENINGKATKAN KEMAMPUAN KOGNITIF SISWA
}

\author{
Mega Ilyasa Wisic ${ }^{1}$ Nana $^{2}$ \\ Universitas Siliwangi Tasikmalaya, \\ Jawa Barat, Indonesia \\ Email: megailyasaw12@gmail.com
}

\begin{abstract}
ABSTRAK: Tujuan penulisan ini untuk mendeskripsikan penerapan model creative problem solving berbasis komik strip dalam pembelajaran fisika untuk meningkatkan kemampuan kognitif siswa. Penulisan ini dilatarbelakangi oleh masih kurangnya pemahaman siswa terhadap materi pembelajaran fisika. Untuk itu perlu ada upaya yang dapat mengatasi permasalahan tersebut dengan menerapkan model creative problem solving berbasis komik strip. Model creative problem solving sebagai proses pemecahan masalah yang berbasis komik strip agar siswa menjadi termotivasi dan dapat meningkatkan hasil belajarnya. Metode yang digunakan dalam penulisan ini adalah studi kepustakaan dengan mengkaji beberapa literatur untuk dianalisis dan dibuat kesimpulan. Hasil penulisan ini menunjukkan bahwa penerapan model creative problem solving berbasis komik strip dalam pembelajaran fisika dapat menjadi solusi dari permasalahan yang ditemui dalam proses belajar mengajar di kelas. Model creative problem solving diterapkan dengan beberapa langkah antara lain: siswa melakukan klarifikasi berbagai masalah untuk dipecahkan, setelah masalah dipilih kemudian diungkapkan melalui komik strip, selanjutnya melakukan proses evaluasi dan seleksi untuk menemukan solusi dari masalah yang ditemukan. Dengan demikian, dapat meningkatkan kemampuan kognitif siswa.
\end{abstract}

Kata Kuci: Komik Strip, Creative Problem Solving, Kemampuan Kognitif

\section{PENDAHULUAN}

Berbagai upaya dalam menciptakan proses pembelajaran yang berkualitas demi mewujudkan tujuan pendidikan nasional. Salah satunya dengan memanfaatkan sarana dan prasarana pendidikan yang dapat mendukung proses belajar mengajar. Dalam kemajuan perkembangan ilmu pengetahuan dan teknologi semakin mendorong berbagai upaya untuk memanfaatkan perkembangan teknologi tersebut. Hasil dari perkembangan teknologi tersebut dapat mendorong pelaksanaan proses belajar mengajar menjadi lebih mudah dan berkualitas.

Tidak dapat dipungkiri banyak sekali hambatan yang dilalui dalam mengaktifkan daya nalar dan kreativitas siswa dikarenakan tingkat intelengensi yang berbeda-beda. Tentu saja hal tersebut menjadi tolak ukur dalam pembelajaran di kelas maupun di luar kelas (Nana, 2018). Proses belajar mengajar bukanlah kegiatan memindahkan pengetahuan dari guru kepada siswa, tetapi suatu kegiatan yang 
memungkinkan siswa merekonstruksi sendiri pengetahuannya sehingga mampu menggunakan pengetahuan dalam kehidupan sehari-hari. Belajar yang efektif dapat membantu siswa untuk meningkatkan kemampuan yang diharapkan sesuai dengan tujuan instruksional yang ingin dicapai (Hamdani, 2011).

Keberhasilan dalam proses belajar mengajar sebaiknya memuat tiga komponen pembelajaran yaitu guru, materi pembelajaran, dan siswa, serta melibatkan sarana dan prasarana seperti berbagai metode atau media pembelajaran. Pemanfaatan media pembelajaran menjadi salah satu upaya untuk pelaksanaan pembelajaran yang lebih mudah dan berkualitas dan dapat menjadi salah satu solusi dari masalah yang ada pada proses pembelajaran.

Berdasarkan masalah yang terjadi untuk memperbaiki proses pembelajaran, diperlukan upaya dengan memanfaatkan media pembelajaran sebagai alat bantu.Media pembelajaran yang digunakan adalah komik strip, karena komik strip diduga sesuai untuk menggambarkan cerita tentang materi pembelajaran. Dengan komik strip diharapkan dapat menyampaikan materi pembelajaran menjadi lebih mudah dan menarik perhatian siswa (Ratnawuri, 2016).

Pembelajaran fisika adalah pembelajaran yang tidak mengabaikan hakikat fisika sebagai sains. Hakikat sains yang dimaksud ini adalah produk, proses, dan sikap ilmiah. Pembelajaran fisika seharusnya dapat memberikan pengalaman langsung agar siswa lebih memahami konsep materi yang dipelajarinya. Tetapi, kebanyakan guru fisaika hanya mengandalkan pembelajaran yang berpusat kepada guru dan juga buku tanpa memanfaatkan media pembelajaran lainnya seperti laboratorium, perpustakaan, media pembelajaran, dan internet sebagai sumber pembelajaran.

Mengatasi permasalahan yang dihadapi pada proses pembelajaran fisika maka perlu ada perubahan pada proses pembelajaran yang berpusat kepada guru menjadi berpusat pada siswa. Perlu dikembangkan pengalaman belajar melalui pendekatan dan inovasi yang mengaitkan antara materi pelajaran dengan permasalahan yang dihadapi serta pemanfaatan sumber belajar secara optimal. Keterlibatan langsung siswa dalam proses pembelajaran diharapkan dapat meningkatkan hasil belajar dan dapat meningkatkan keterampilan berpikir dalam memecahkan masalah. Salah satu solusi yang bisa ditawarkan adalah pembelajaran konstruktif dan berpusat pada pemecahan masalah yaitu penerapan model pembelajaran creative problem solving (Hariawan, dkk, 2013), 
Kurangnya keterlibatan siswa dalam pembelajaran yaitu dikarenakan siswa kurang berusaha untuk mencari materi pembelajaran sendiri, dan hal ini mengurangi makna dari pemebelajaran yang efektif dan aktif. Para siswa cenderung belajar untuk dapat menjawab soal-soal ulangan dengan metode menghafal materi saja bukan dengan memahami, menganalisis suatu permasalahan, dan memecahkan masalah yang mungkin dihadapi dalam kehidupan seharihari, sehingga cara berpikir kritisnya kurang terlatih. Akibatnya kemampuan kognitifnya juga pun menjadi kurang terlatih. Dengan menggunakan model pembelajaran creative problem solving, siswa akan melalui proses diantaranya: membuat atau mencari masalah, melakukan proses evaluasi dan seleksi untuk menemukan solusi dari masalah yang ditemukan.

\section{METODE PENELITIAN}

Metode yang digunakan dalam penulisan ini berupa studi kepustakaan. Data dikumpulkan untuk dianalisis kemudian disajikan dalam hasil dan pembahasan agar dapat dibuat kesimpulan.

\section{HASIL DAN PEMBAHASAN}

\section{Creative Problem Solving}

Model CPS adalah suatu model pembelajaran yang melakukan pemusatan pada pengajaran dan keterampilan pemecahan masalah, yang diikuti dengan penguatan keterampilan (Supardi, dkk, 2010). Creative problem solving (pemecahan masalah kreatif) dalam penyelesaian problematik maksudnya segala cara yang dikerahkan oleh seseorang dalam berpikir kreatif, dengan tujuan menyelesaikan suatu permasalahan secara kreatif (Hariawan, dkk, 2013). Pemecahan masalah yang membutuhkan kreativitas dengan mendefinisikan berbagai pertanyaan untuk diselesaikan dan dicari solusinya. Penting sekali dalam memahami struktur masalah dengan berbagai pemikiran kreatif. Proses pemecahan masalah melibatkan pengalaman baru yang secara logis di susun dengan sistematis. Masalah juga perlu dilihat dan diketahui kebenarannya (Ridong $\mathrm{Hu}$ et al dalam Nana, 2018). Langkah-langkah dalam model creative problem solving antara lain sebagai berikut; proses pemecahan masalah dengan kreatif dengan menyeleksi informasi baru, masalah yang telah diindentifikasi kemudian di konsep secara komprehensif, proses masalah yang telah di konsep untuk menemukan solusi dari masalah yang nyata (Basadur el al dalam Nana , 2018). 


\section{Komik Strip}

Komik strip (strip comics) didefinisikan oleh Arjuna (dalam Ratnawuri, 2016) sebagai sebuah gambar atau rangkaian gambar yang berisi cerita. Gambar-gambar dirangkai dalam komik strip terdiri dari tiga sampai enam panel. Gambar tersebut dirangkai dengan muatan cerita tertentu. Komik yang bisa dikatakan sebagai media pembelajaran apabila isi cerita komiknya memenuhi unsur-unsur pembelajaran, sehingga tidak hanya memiliki aspek menghibur. Komik pembelajaran juga harus bisa memenuhi tujuan instruksional atau tujuan pembelajaran dari setiap materi yang diceritakan dalam isinya, yaitu memuat materi pembelajaran sesuai dari pokok bahasan materi yang akan disampaikan (Ratnawuri, 2016).

\section{Kemampuan Kognitif}

Kemampuan kognitif merupakan kegiatan mental dari tahap dasar ke tahap yang lebih tinggi yang dilakukan oleh seseorang dalam berpikir yang meliputi aspek mengingat (C1), memahami (C2), mengaplikasikan (C3), menganalisis (C4), mengevaluasi (C5), dan mencipta (C6) (Anderson, \& Krathwohl dalam siswanto, dkk, 2001). Perlu adanya inovasidan perbaikan kualitas belajar agar siswa dapat mengetahui kesalahan belajarnya untuk kemudian diperbaiki, sehingga mampu meningkatkan perolehan kemampuan kognitif siswa (Alfiah, dkk, 2018).

\section{Penerapan Model Creative problem solving Berbasis Komik Strip dalam Pembelajaran Fisika untuk Meningkatkan Kemampuan Kognitif Siswa}

Salah satu permasalahan dalam proses pembelajaran yaitu bagaimana mengembangkan metode atau media pembelajaran agar siswa dapat lebih mudah memahami suatu materi yang sedang diajarkan dan juga pembelajaran menjadi berkualitas, maka dari itu dengan menggunakan media pembelajaran seperti komik strip siswa akan menjadi lebih dapat dengan mudah memahami materi pembelajaran seperti pembelajaran fisika yang diangap sulit. Dengan komik strip diharapkan dapat menyampaikan materi pembelajaran menjadi lebih mudah dan menarik perhatian siswa (Ratnawuri, 2016).

Creative problem solving merupakan salah satu pemecahan masalah secara kreatif yang dianggap berpengaruh pada kreativitas siswa di masa depan. Beberapa peneliti menyakini bahwa kreativitas berupa masalah yang akan dipecahkan, sejumlah ide yang relevan, proses memberikan solusi dari divergen ke kovergen (Lin dalam Nana, 
2018). Sebagaimana penjelasan sebelumnya bahwa masalah dapat dipecahkan dengan mengindentifikasi dan menyeleksi masalah sesuai dengan kreatif (Wimmer dalam Nana, 2018). Proses mengindentifikasi dengan model pemecahan masalah secara kreatif maka diperlukan pembaharuan yang berbasis teknologi dengan komik strip.

Para siswa cenderung belajar untuk dapat menjawab soal-soal ulangan dengan metode menghafal materi saja bukan dengan memahami, menganalisis suatu permasalahan, dan memecahkan masalah yang mungkin dihadapi dalam kehidupan seharihari, sehingga cara berpikir kritisnya kurang terlatih. Akibatnya kemampuan kognitifnya juga pun menjadi kurang terlatih. Dengan menggunakan model pembelajaran creative problem solving, siswa akan melalui proses diantaranya: membuat atau mencari masalah, melakukan proses evaluasi dan seleksi untuk menemukan solusi dari masalah yang ditemukan. Dengan demikian, kemampuan kognitif siswa pun akan meningkat dengan model pembelajaran creative problem solving.

\section{PENUTUP}

Dari berbagai pembahasan yang telah dijabarkan dapat ditarik kesimpulan dan dimaknai bahwa model pembelajaran yang berbasis masalah secara kreatif dapat meningkatkan motivasi siswa agar lebih terpacu dalam keberhasilan belajarnya dan juga meningkatkan kemampuan kognitif siswa. Kesesuaian keterampilan dan bakat siswa dapat berpengaruh pada hasil yang dicapai sehingga perlunya keprofesionalan guru sebagai pengajar agar dapat menjadikan siswa menjadi lebih kreatif dengan media pembelajaran berupa komik strip.

\section{UCAPAN TERIMAKASIH}

Terima kasih kepada semua pihak yang telah membantu demi kesempurnaan artikel ini menjadi lebih baik.

\section{DAFTAR PUSTAKA}

Alfiah, A. N., Putra, N. M. D., \& Subali, B. (2018). Media Scrapbook sebagai Jurnal Refleksi untuk Meningkatkan Kemampuan Kognitif dan Regulasi Diri. Jurnal Pendidikan (Teori dan Praktik). 3(1): 57-67.

Hamdani. 2011. Strategi Belajar Mengajar. Bandung: CV. Pustaka Setia. 
Hariawan, Kamaluddin, \& Wahyono, U. (2013). Pengaruh Model Creative Problem Solving terhadap Kemampuan Memecahkan Masalah Fisika pada Siswa Kelas XI SMA Negeri 4 Palu. Jurnal Pendidikan Fisika Tadulako. 1(2): 48-54.

Nana. (2018). Penerapan Model Creative Problem Solving sebagai Inovasi Pembelajaran di Sekolah Menengah Atas dalam Pembelajaran Fisika. (Seminar Nasional Fisika dan Aplikasinya). 3. 190. 10.20961/prosidingsnfa.v3i0.28544.

Ratnawuri, T. (2016). Pemanfaatan Komik Strip sebagai Media Pembelajaran Mahasiswa Pendidikan Ekonomi UM Metro. Jurnal Studi Pendidikan Ekonomi. 4(2): 8-12.

Supardi, K. I., \& Putri, I. R. (2010). Pengaruh Penggunaan Artikel Kimia dari Internet pada Model Pembelajaran Creative Problem Solving. National Scientific Journal of Unnes. 4(1): 574-581. 